\title{
The Object of the Right Concept for State Ownership of Land
}

\author{
Andrey A. Nikulin*1, Oksana A. Begisheva ${ }^{2}$ \\ ${ }^{1,2}$ Kazan Federal University, The Department of Civil Law and Civil Procedure, \\ Email: and-nik@yandex.ru, Contact: 89625653804,o.beg@mail.ru
}

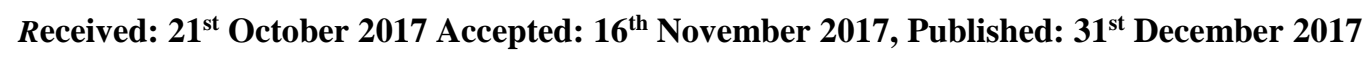

\begin{abstract}
The state as a party to ownership relations concerning land and other natural resources has a certain specificity. Civil lawyers have repeatedly noted the dualism of its nature and the fact that the state simultaneously plays the role of regulator of relations concerning all lands under its jurisdiction, as well as the owner of land plots, and enters into specific legal relations, making legally significant decisions on property objects as an economic entity. In this regard, it is interesting to consider the issue of a property item as to the state ownership of land.

The methodological basis of the study was the general methods of research: analysis, synthesis, and generalization, the integrated approach method, analogies, also special ones: comparative legal, formal legal.

As a result of the analysis of normative legal acts and approaches to the definition of the object of civil and land legal relations set out in the legal literature, the definition of the object of the right for the state ownership of land was formulated, and differences were found in such legal categories as "land", "land plot", "natural object", "natural resource", and the use of the term "object of nature management" was proposed.

The conclusion was made that the terms "land" and "land plot" are used equivalently in the Russian legislation and legal literature to mean the object of ownership right.

The peculiarities of an object of the right for state ownership of land and its legal attributes characterizing a land plot as a natural resource and as an object of state property right are revealed.
\end{abstract}

Keywords: Land Plot, Natural Object, Natural Resource, Object of Nature Management, State Ownership.

\section{Introduction}

Despite the fact that the Constitution of the Russian Federation establishes a variety of forms of ownership, at present, state ownership is the priority form of ownership of land, other natural objects and resources. Land law, which is entrusted in the Russian legal system with the task of regulating the legal status of the land, is one of the most dynamically developing branches of law. This fact is confirmed by the fact that the Land Code of the Russian Federation (hereinafter referred to as the RF LC), which is the main normative legal act regulating land relations, has been changed more than 100 times since its introduction in 2001. At the same time, the question remains: what is the object of ownership: a natural resource, a natural object or both? The solution of this issue is the main goal of this study.

The concepts, conclusions and proposals formulated in the paper can be used by teachers in the educational process when lecturing the course "Land Law" and in the development of special courses. Theoretical conclusions and proposals can be used by researchers in conducting research in land and civil law on this and other topics, as well as in developing new and improving the current legislation.

\section{Materials and Methods}

The study of the set of problems identified in this study was primarily carried out through the wide application of general scientific methods. At the same time, as in any field of jurisprudence, it was necessary to apply in this study also special legal scientific methods, such as the method of legal dogmatics and the method of comparative jurisprudence.

In view of the complexity of the object of research and its multidimensional essence, the methods used were applied exclusively within the system approach.

The theoretical basis of the research was the work of both Russian and foreign scientists - experts in the field of land law.

Normative basis of the research was made by the domestic regulatory legal acts regulating public relations related to the land.

\section{Results and Discussion}

Analysis of the legislation showed that the definitions of such concepts as "objects of nature management", "natural resources as objects of civil legal relations" are not enshrined. The Land Code of the Russian Federation determines in the capacity of objects of land relations not only land plots and parts of land plots, but also land as a natural object and a natural resource. In the scientific literature and in the content of the regulatory acts themselves, there is no unity of application of such definitions as "natural resource", "natural object", "object of nature management", which are often used as synonyms. This, in turn, leads to a mixture of legal concepts [1]. Criteria for the delimitation of land and other natural resources as objects of civil law relations from such legal categories as "components of the natural environment" or "natural object" have not been developed by science, and it is difficult to draw such conclusions from the provisions of the law. Given the dualism of such a special owner 
as the state, it is relevant to consider the issue of the state ownership of land.

From our point of view, in the legal literature there is a valid opinion about the need for legislative consolidation of such a concept as an "object of nature management"[2,3]. One of the main features of natural objects as components of the natural environment (including land) is that they in their natural state are objects of nature, are in indissoluble connection with the environment, and affect its quality. If a certain legal regime is established with respect to land, it can be regarded as a natural resource, or an individually defined part of a natural object that becomes an object of a land property relationship, so the use of the term "object of nature management" is appropriate.

The term "natural resource" has received a legislative definition in Article 1 of the Federal Law "On Environmental Protection", however, it does not reflect the constitutional legal status of the concept of a natural resource as an object of ownership. Instead, the legislator's key emphasis was shifted to the fact that natural resources are of consumer value and can be used for economic and other activities. Undoubtedly, the process of consuming a natural resource is associated with the use of a natural object, which in turn is impossible without exercising by the owner of its right to use the object. Article 130 of the Civil Code of the Russian Federation (hereinafter referred to as RF CC) refers to the objects of nature management which are subject to civil regulation as non-movable assets objects, including land plots and subsoil plots. They are included in the civil turnover and are part of the nonmovable assets. Their availability in turnover is allowed only in cases and within the limits established by special (nature-resource) legislation.

The question of the status of the land as an object of property rights is relevant in and of itself, but it acquires an exceptional value for the state. Often, the concepts of "land" and "territory" are completely identified. However, as O. I. Krassov notes, the right of territorial supremacy concerns only the sphere of international relations. Therefore, the right of territorial supremacy is not related to the right of state ownership of natural resources, including land [4].

The object of the right for the state ownership of land is defined in the legislation rather vaguely. So, in accordance with paragraph 2 of Article 214 of the Civil Code of the Russian Federation, land and other natural resources that are not owned by citizens, legal entities or municipal entities are state property. This generates the so-called presumption of state ownership of land. In this regard, the notion of "land of non-delineated state ownership" is often used in legislation and in legal literature to designate those plots for which neither the Russian Federation, nor the subjects of the Russian Federation, nor municipal entities have registered their right in the established order.

At the present time, the current Russian legislation as an object of ownership of land, as in the Land Code of the Russian Federation and in other laws, refers to two concepts - "land" and "land plot". For example, the Civil Code of the Russian Federation contains provisions on land rights, transactions with land and so on. So in Articles130, 132, 216, 261, etc., the term "land plot" is used, and the term "land" in articles126, 129,214 and others.

The Land Code of the Russian Federation is also not an example of the unity of terminology. Thus, Article 1, paragraph 1, deals with land as an object of property rights and other rights, and as a non-movable assets object. Chapter V of the Land Code of the Russian Federation is called "The emergence of rights to land". Obviously, rights do not arise to land in general, but to a specific land plot.

In the Constitution of the Russian Federation, the term "land plot" is not mentioned at all, but the Constitution refers to land, including the right to own it. A characteristic situation can be observed on the example of legal norms on the right of ownership of natural resources contained in natural resources legislation. It can be concluded that in the Russian legislation and legal literature, the terms "land" and "land plot" are identified when specifying an object of ownership.

With the entry into force of the amendments to the Land Code of the Russian Federation, Part 3, Article 6 of the Land Code of the Russian Federation gives a new, third (for the period of the existence of the Code) definition of the concept "land". Of extreme practical importance is not only the wording of this term, but also its delimitation from other related terms used in land legislation. This is justified by the fact that full ownership and use is possible only in respect of a land plot that meets the requirements contained in the legislation. Unlike the previous legislative definitions, the legislator emphasized in the new definition of the term "land plot" that it is an immovable thing that is a part of the earth's surface and has characteristics that make it possible to define it as an individually defined thing. Compared with the previous interpretation, the definition does not include an indication of a land plot as a presence of a soil layer; therefore, in accordance with the indicated changes in land legislation, the soil is no longer an obligatory component of the land plot. Relatively new is the fact that in cases and in the manner established by the federal law, artificial land plots can be created.

There stay unchanged in the definition an indication that a land plot is "part of the earth's surface". This approach is consistent with the definition of the land used in German law and in the literature on German law [5,6], but at the same time, the definition of spatial boundaries of a land plot as a means of identification under Russian and German legislation is fundamentally different.

According to the provisions of the German Civil Code (Bürgerliches Gesetzbuch, BGB), the right of an owner of a land plot extends to the space above and below the surface layer of the plot. Interesting is the conclusion of the German scientist, Professor V.B. Sheunemann, made on the basis of the analysis of the abovementioned provision from the BGB. This conclusion says that a land plot in the legal sense is not only a fragment of the earth surface registered in the land cadastre (measured and documented in the public 
register), but also the volume of space (the turning pyramid) which top is the center of the Earth and which faces extend in infinite horizons of the Universe [7].

The Russian legislation defines the spatial boundaries of a land plot more narrowly. Thus, Article 261 of the Civil Code of the Russian Federation does not extend the ownership of the land plot to everything that is above and below the surface of the land plot, instead indicating that the owner is entitled to use such facilities at own discretion, unless otherwise established by law.

It should also be remembered that a land plot as an object of property right is an immovable thing. The list of non-movable assetsu is given in article130 of the Civil Code. It includes land plots, subsoil plots and everything that is firmly connected with the land, that is, objects which displacement without disproportionate damage to their destination is impossible, including buildings, structures, and incomplete construction projects.

This is closest to the approach that exists in German legislation, where it is the land plot that appears for the main non-movable assets object. Movable things, firmly connected with the soil (buildings, plantings, etc.) are called "essential constituents" of a land plot. There is a physical unity of the land and these objects, and the latter cannot be the subject of special rights, because they are part of a single non-movable assets object [8]. In this case, unlike French and Italian legislation, which considers a land plot as one of the types of non-movable assets, German legislation identifies in the capacity of the main criterion for classifying property as immovable an inextricable link with the land plot. In Anglo-American law it is believed that its subjects possess not the land plots (things) themselves, but only legal titles to them (estate), since the land can only belong to the "crown" (the highest public authority), and "full ownership" is possible only with respect to movable property [9].

Regardless of its origin, a land plot requires identification and registration in cadastre, since the property object must be individually identified. The possibility and procedure for the implementation of this duty is provided for by a number of existing laws, especially the new Federal Law dated 13.07.2015. "On state registration of non-movable assets" and is a condition for registration of rights and transactions which involve a special order.

In accordance with paragraph 2 of Artcle 8 of the Civil Code of the Russian Federation, the rights to property which are subject to state registration arise precisely from the moment of registration of the corresponding rights to it, unless otherwise established by law. The practical significance of this provision is manifested in the fact that without a state registration of rights to a land plot, even if there is an act of a state or municipal body, a contract or a court decision granting (establishing, recognizing) the right to a land plot, an agent does not have legal grounds for exercising its powers in respect of the land plot [10].
It should be noted that the legislator does not provide for the need for state registration of "lands" in the Unified State Register of Non-movable assets, because only the particular specified property described in the prescribed manner can be an object of ownership. Only a land plot with its location, boundaries, etc. can be described and specified. In addition, the Federal Law "On the Enactment of the Land Code of the Russian Federation" specifically provided that the lack of state registration of ownership of land plots which state ownership is not delineated is not an obstacle to the implementation of the right of administration and disposal of them (Clause 1, Article 3.3).

\section{Summary}

Thus, it is possible to distinguish some features of an object of state ownership of land. Firstly, it should be an identified land plot, the right to which is registered by the procedure established by law. Secondly, the state is given the right to own land plots, regardless of their turnover capability. Only in the property of the Russian Federation there are lands withdrawn from turnover. Constituent entities of the Russian Federation can have in their ownership land plots of limited turnover.

One should consider in the capacity of the main legal features that characterize the land (and, more accurately, the land plot) as a natural resource and in the capacity of an object of state ownership, first, its socially significant character, and secondly, the ability of the public authorities to individualize (isolate) it, thirdly, the existence of an absolute legal binding, that is, the condition of regulatory and legal support of a land plot ownership to a particular owner with the exclusion of the possibility of existence "orphaned" natural resources, which is guaranteed by a number of legal and technical mechanisms (the proclamation of exclusive state property, securing the presumption of public ownership of objects not related to private property, and criterial object-level delineation of public property).

It is necessary to distinguish as an additional (optional) feature the complex nature of such a natural resource as land, which is both an object of the natural environment and of property right. As a part of the inclusion of land in economic turnover, it requires an integrated approach in assessing, operating, and ensuring rational use and protection. It is the land that is the basis for locating such natural objects as forests and water. Their availability within the boundaries of a land plot dictates both the form of ownership and the possibility of including the plot in turnover and requires consideration of the norms of both land and natural resource legislation. Such a complex approach seems justified, since otherwise artificial "titular differentiation" of constituent elements of complex natural resources impedes both stability and streamlining of civil commerce in the sphere of nature management, and significantly complicates the implementation of environmental policy and the fulfillment by the owners of natural resources and nature users of their environmental responsibilities, 
violating mandatory prescriptions of the Constitution of the Russian Federation.

\section{Conclusion}

In summary, the following definition can be proposed. The object of the right for state ownership of land is a land plot which is an individually defined part of the land surface of a specific purpose within the boundaries of the territory of the Russian Federation, determined by law, and the state property right to which is registered in accordance with the procedure established by law.

\section{Acknowledgements}

The work is carried out according to the Russian Government Program of Competitive Growth of Kazan Federal University.

\section{References}

1. Biryukova N. V. Natural non-movable assets: the rationale for the allocation of natural resources in the capacity of special objects of civil law as part of immovable property // Russian Justice. - 2008. - No. 8.- P. 20-22.

2. Makerov I. V. On the term of long-term bank lending / / Law and Economics. - 2015. - No. 9.- P. 71 $-76$.
3. Nikishin V. V. Determination by courts of appropriate ways to protect the rights of nature users / / Russian legal journal. - 2015. - No. 1.- P. 170 - 181.

4. O.I.Krassov. Land law: a textbook / O.I. Krassov. 5th edition, revised and enlarged - M. : Jur. Norm, SIC INFRA-M, 2017. - 560 p.

5. Münchener Kommentarzum Bürgerlichen Gesetzbuch. Band 1, Allgemeiner Teil.§§ 1-240 AGBGesetz / Redakteur F.J. Säcker. - 4. Auflage. München: Verlag C.H. Beck, 2001. - P. 905.

6. Berger C. Allgemeines Grundstücksrecht. // Immobilienrecht. Handbuch. 2, überarbeitete und erweitere Auflage. Schreiber K. (Hrsg.). Berlin. 2005. P. 74.

7. Schünemann W.B. Wirtschaftsprivatrecht: juristisches Basiswissen für Wirtschaftswissenschaftler. - 4., neubearbeit. Aufl. Stuttgart: Lucius und Lucius, 2002. - P. 55.

8. Baur F., Baur J.F., Stumer R. Sachenrecht. 16. Aufl. Munchen, 1992. P. 10-12.

9. Reimann M. Einfuehrung in das US-amerikanische Privatrecht. 2. Aufl. Muenchen, 2004. P. 131 - 1329.

10. Totochenko D.A.A land plot and a part of the land plot as objects of civil protection in a court // Property relations in the Russian Federation. - 2016. - No. 7.- P. $6-13$. 